\title{
The 2002 rock/ice avalanche at Kolka/Karmadon, Russian Caucasus: assessment of extraordinary avalanche formation and mobility, and application of QuickBird satellite imagery
}

\author{
C. Huggel ${ }^{1}$, S. Zgraggen-Oswald ${ }^{1}$, W. Haeberli ${ }^{1}$, A. Kääb ${ }^{1}$, A. Polkvoj ${ }^{2}$, I. Galushkin ${ }^{3}$, and S. G. Evans ${ }^{4}$ \\ ${ }^{1}$ Glaciology and Geomorphodynamics Group, Geography Department, University of Zurich, Switzerland \\ ${ }^{2}$ Department of Natural Resources and Environment Protection, Vladikavkas, North Ossetia, Russia \\ ${ }^{3}$ InfoTerra, Vladikavkas, North Ossetia, Russia \\ ${ }^{4}$ Department of Earth Sciences, University of Waterloo, Canada
}

Received: 13 September 2004 - Revised: 3 January 2005 - Accepted: 10 January 2005 - Published: 31 January 2005

Part of Special Issue "Landslides and debris flows: analysis, monitoring, modeling and hazard"

\begin{abstract}
A massive rock/ice avalanche of about $100 \times 10^{6} \mathrm{~m}^{3}$ volume took place on the northern slope of the Kazbek massif, North Ossetia, Russian Caucasus, on 20 September 2002. The avalanche started as a slope failure, that almost completely entrained Kolka glacier, traveled down the Genaldon valley for $20 \mathrm{~km}$, was stopped at the entrance of the Karmadon gorge, and was finally succeeded by a distal mudflow which continued for another $15 \mathrm{~km}$. The event caused the death of ca. 140 people and massive destruction. Several aspects of the event are extraordinary, i.e. the large ice volume involved, the extreme initial acceleration, the high flow velocity, the long travel distance and particularly the erosion of a valley-type glacier, a process not known so far. The analysis of these aspects is essential for process understanding and worldwide glacial hazard assessments. This study is therefore concerned with the analysis of processes and the evaluation of the most likely interpretations. The analysis is based on QuickBird satellite images, field observations, and ice-, flow- and thermomechanical considerations. QuickBird is currently the best available satellite sensor in terms of ground resolution (0.6 $\mathrm{m})$ and opens new perspectives for assessment of natural hazards. Evaluation of the potential of QuickBird images for assessment of high-mountain hazards shows the feasibility for detailed avalanche mapping and analysis of flow dynamics, far beyond the capabilities of conventional satellite remote sensing. It is shown that the avalanche was characterized by two different flows. The first one was comparable to a hyperconcentrated flow and was immediately followed by a flow with a much lower concentration of water involving mas-
\end{abstract}

Correspondence to: C. Huggel

( chuggel@geo.unizh.ch) sive volumes of ice. The high mobility of the avalanche is likely related to fluidization effects at the base of the moving ice/debris mass with high pore pressures and a continuous supply of water due to frictional melting of ice. The paper concludes with implications of the Kolka/Karmadon event for worldwide glacial hazard assessments. It is emphasized that situations with large glacierized high-mountain walls with potentially unstable glaciers within impact distance need special attention and monitoring efforts.

\section{Introduction}

In the evening of 20 September 2002, a large rock/ice avalanche took place on the northern slope of the Kazbek massif, North Ossetia, Russian Caucasus. The avalanche started as a slope failure in the NNE face of Dzhimarai-khokh (4780 m a.s.l.) below the summit and involved massive volumes of rock and ice (from hanging glaciers). The slide impacted Kolka glacier which was entrained to a major extent by disruption and liquidization. The rock/ice avalanche which then formed had a volume of about $100 \times 10^{6} \mathrm{~m}^{3}$ and travelled down the Genaldon valley for $20 \mathrm{~km}$ before being stopped at the entrance of the Karmadon gorge. A mudflow, however, continued downvalley for another $15 \mathrm{~km}$ and stopped $4 \mathrm{~km}$ before reaching the town of Gisel (Figs. 1 and 2). Several millions of cubic meters of sediment were deposited during the 2002 event along the Genaldon and Giseldon river beds. Both, the avalanche and the distal mudflow, were completely devastating, caused the death of about 140 people and destroyed important traffic routes, residential buildings and other infrastructures. The ice/debris deposits at Karmadon dammed several marginal lakes of up to 


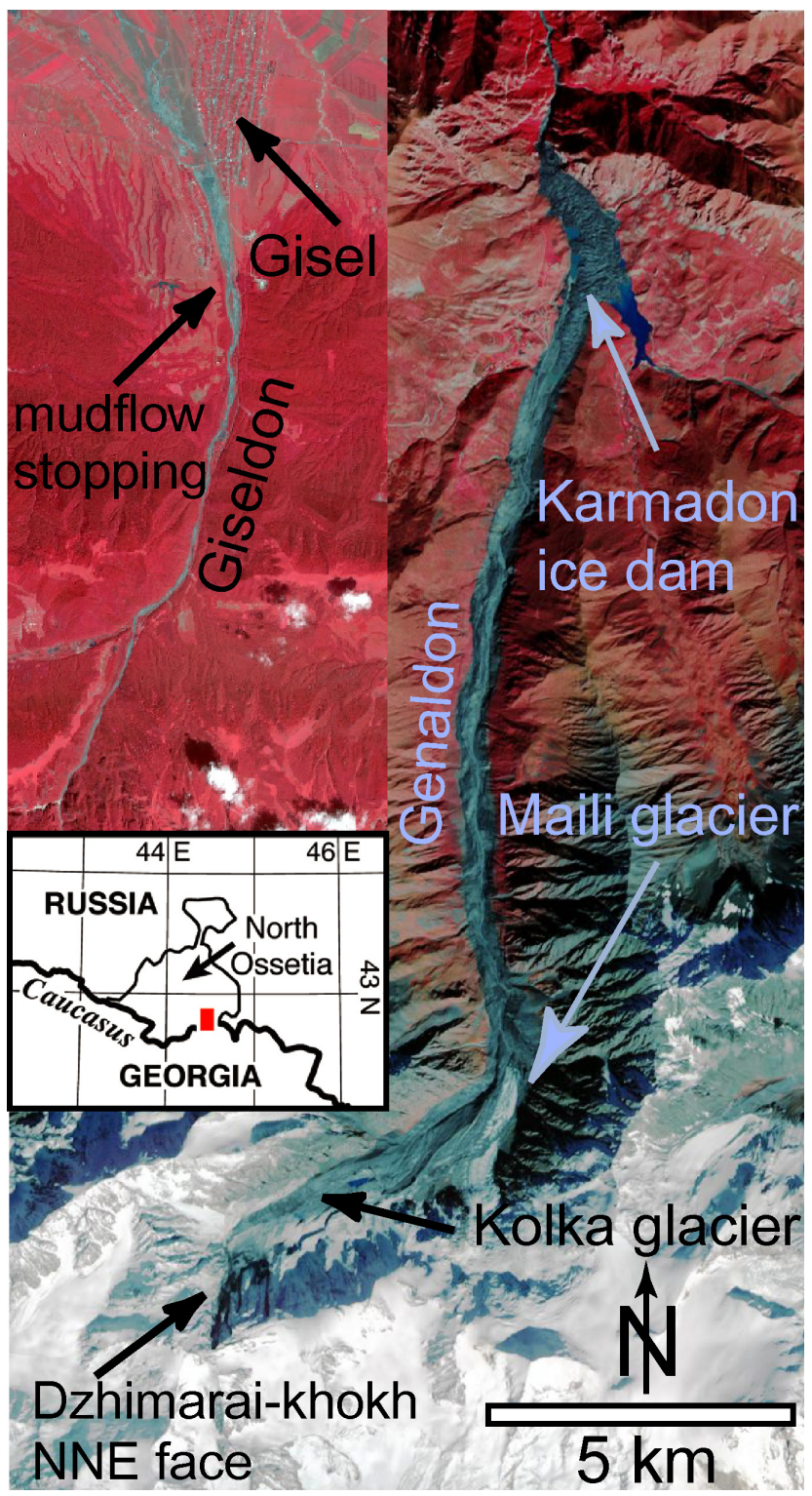

Fig. 1. Overview of the avalanche and distal mudflow zone. The avalanche zone is shown by an ASTER satellite image from 6 October 2002, the distal mudflow zone (not in scale) by an ASTER image from 22 July 2001.

$5 \times 10^{6} \mathrm{~m}^{3}$ of water. Potential floods from these lakes were an imminent threat to the downstream areas after the disaster (Kääb et al., 2003a; Haeberli et al., 2005).

Large rock/ice avalanches are rare but not uncommon in high-mountain regions (e.g. Evans and Clague, 1988). Several aspects of the Kolka event are, however, extraordinary, among them the extreme acceleration of the avalanche mass on a moderately inclined slope, the high flow velocity, the long travel distance, and particularly the almost complete erosion of a valley-type glacier. The Kolka avalanche is furthermore the largest historically documented ice avalanche so far. According to the characteristics observed, the avalanche is difficult to assign to sediment-water

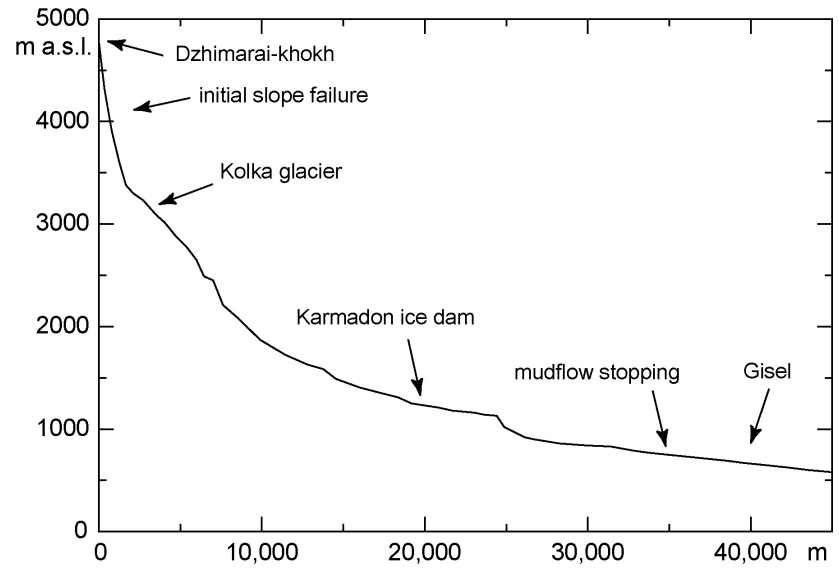

Fig. 2. Longitudinal cross section along the avalanche and distal mudflow track.

flow or landslide classifications such as suggested by Pierson and Costa (1987) or Hungr et al. (2001), and actually does not correspond to classical rock avalanches in various aspects (e.g. higher concentration of water involved). Due to the unusual processes, this event can represent serious implications for worldwide glacial hazard assessments. The objective of this study is therefore to analyze the event and the involved processes and to draw conclusions as far as possible. Since the event is particularly difficult to interpret and analyze, a wide range of opinions and speculations arose after the disaster. Here it is attempted to outline which interpretations are realistic or not, based on ice-, flow- and thermomechanical considerations and on satellite image analysis. The three main sections of slope failure (Sect. 4), glacier erosion (Sect. 5) and avalanche dynamics (Sect. 6) are split into observations and assessment/interpretation in order to enable a sound analysis.

Observation and analysis are strongly based on QuickBird satellite images which have the currently best available spatial resolution of $0.6 \mathrm{~m}$. The recent emergence of commercial satellite sensors with very-high ground resolution, comparable to aerial photography, such as IKONOS, QuickBird or Orbview-3 (Birk et al., 2003) opens new perspectives for applications in the area of natural hazards. These may range from detailed mapping and assessment to disaster management and response (cf. Kerle and Oppenheimer, 2002). Presumably due to the recent emergence of the satellite and high image acquisition costs, studies on the application of QuickBird data for high-mountain hazards are yet largely missing. It is the intention of this paper to evaluate the potential of this data for the aforementioned objective of process analysis and mapping and assessment of high-mountain hazards.

\section{Physical conditions}

The Kazbek massif where the avalanche started is a volcanic area including Mount Kazbek volcano (5030 m a.s.1.) and a series of smaller monogenic volcanoes located within 
the central sector of the Greater Caucasus structure. The Kazbek-Tskhinvali cross deep fault is controlling the volcanic area. Major thrust faults run through the 2002 avalanche starting area (Haeberli et al., 2005). Volcanic formations are predominantly lavas and pyroclastic rocks (Tolstykh et al., 2001). The present volcanic activity of Mount Kazbek is not completely clear, but can be regarded as dormant. Geochemical observations and analyses suggest the proximity of magmatic bodies indicated by degassing of magmatic reservoirs (Polyak et al., 2000).

The tectonically active area does also feature spots of geothermal activity. Hot springs occur in the area of the Kazbek massif: the name of the nearby village Karmadon ("warm water") relates to hot springs in the valley. Field observations revealed several hot springs in the area close to the tongue of Maili glacier. The geothermal heat flow is, in fact, slightly enhanced in the Kazbek massif with values of about $100 \mathrm{~mW} / \mathrm{m}^{2}$ (Polyak et al., 2000).

The initial slide detached in the Dzhimarai-khokh NNE wall at around $4300 \mathrm{~m}$ a.s.1., ca. $500 \mathrm{~m}$ below the summit of Dzhimarai-khokh. The NNE face is more than $1000 \mathrm{~m}$ high. Kolka glacier is located at the base of the mountain wall between 3000 and $3300 \mathrm{~m}$ a.s.l. The glacier length before the 2002 avalanche was ca. $3500 \mathrm{~m}$ with an area of ca. $2.5 \mathrm{~km}^{2}$, an estimated volume of $100-150 \times 10^{6} \mathrm{~m}^{3}$ and a moderate slope of $5-10^{\circ}$. Kolka glacier is known as a surging glacier, characterized by quiescent phases and phases of accelerated glacier flow speed (up to 2 orders of magnitude faster ice flow) accompanied by rapid and strong glacier advances. The last surge dates from 1969/1970 and was described in detail by Rototaev et al. (1983).

The glacier valley is first directed WSW-ENE and then turns to S-N at the point where Maili glacier joins the valley. Maili glacier descends from the basin between Mount Kazbek and Mount Maili to an elevation of ca. 2400 m a.s.l. Lateral moraines of both Kolka and Maili glaciers are prominent features in this upper part of the Genaldon valley (Fig. 1). The main deposits of the avalanche are situated $17 \mathrm{~km}$ from the Dzhimarai-khokh NNE face. The ice dam, which formed at Karmadon, was initially $2.5 \mathrm{~km}$ long, 0.5 to $1 \mathrm{~km}$ wide and approximately $100 \mathrm{~m}$ high. The Genaldon gorge continues downvalley but widens after a few kilometers before the confluence with Giseldon river $8 \mathrm{~km}$ downstream from the ice dam.

\section{Methods and data used}

\subsection{QuickBird satellite images}

QuickBird, launched in late 2001, is the first (non-military) spacecraft that offers sub-meter resolution imagery. Together with IKONOS (1 m) and Orbview-3 (1 m), QuickBird represents a new generation of satellite sensors which open new perspectives in earth surface mapping and analyses. QuickBird has a black and white (panchromatic) band with $0.6 \mathrm{~m}$ ground resolution and four multispectral bands ( 3 bands in the visible and 1 band in the near-infrared spectrum) with $2.5 \mathrm{~m}$ resolution. QuickBird features sensor pointing capabilities which allow a revisiting time of 1-3.5 days. The swath width is $16.5-19 \mathrm{~km}$. A disadvantage of QuickBird imagery is the high cost of about USD 24 per km² (Standard imagery product; Digitalglobe, 2004).

Four scenes of the Ortho Ready Standard format from 25 September 2002, i.e. five days after the disaster, were acquired in order to cover the whole avalanche and mudflow track. The images were georeferenced and corrected for topographic distortions showing a georeferencing error of 10 $30 \mathrm{~m}$. Difficult collection of ground reference and limited accuracy of the cartographic/topographic basis hampered a more accurate correction. To study the Kolka avalanche, both, panchromatic and multispectral, images were used.

\subsection{Additional data}

Geometric and topographic correction of satellite images requires a cartographic basis and a digital elevation model (DEM). Here the only maps available were Russian topographic maps of 1:100 000 and 1:25000 scale, 30-40 years old. In absence of a feasible DEM, stereo images from ASTER satellite data were used to generate a $30 \mathrm{~m}$-spaced DEM (Kääb, 2002). ASTER satellite images were also applied for pre- and post-event analysis including the monitoring of marginally dammed lakes at the ice dam in Karmadon (Kääb et al., 2003a). DEMs could furthermore support mapping of the avalanche track and corresponding dynamical calculations. Several field visits were undertaken during 2003 though the access to the avalanche starting area was difficult. Field observations of the ice dam, the avalanche transit zone and the Maili and Kolka glaciers could be made and important information gathered. In addition, regular helicopter flights were started from 21 September 2002, and continued through 2003 and 2004. Photographs taken during these flights allowed insight information on areas not accessible by foot and served as an advantageous complementary source to satellite images for reconstruction and analysis of processes.

\section{Initial slope failure}

\subsection{Observations}

The 2002 avalanche starting zone in the Dzhimarai-khokh NNE wall mainly consists of volcanic and metamorphic rock layers oriented towards NE and inclined by about $35-40^{\circ}$. A system of fissures cuts through the bedrock layers. The average inclination of the slope is around $40-45^{\circ}$, and the heavily fractured rocks are characterized by foliation that appears to daylight in the slope such that an unfavorable (in terms of slope stability) bedding approximately parallel to the slope orientation exists.

Slope instabilities in the Dzhimarai-khokh NNE wall have already been observed in the summer months of 2002 prior to the main avalanche event. Mountain climbers reported widespread and significant rock and ice failures and related 


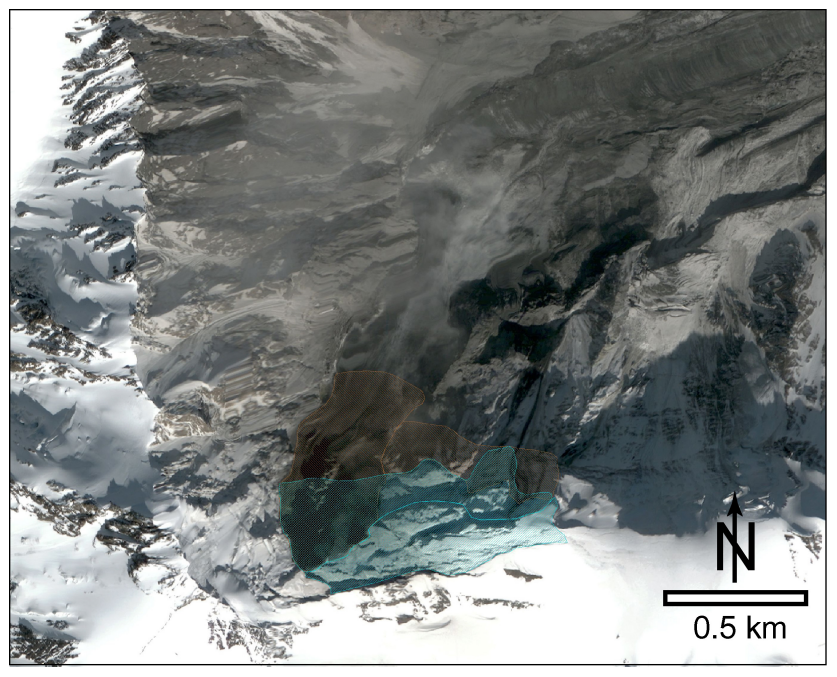

Fig. 3. QuickBird satellite image showing Dzhimarai-khokh NNE face with the slope failure and the upper Kolka glacier. Areas of ice (blue) and rock (brown) failure mapped are indicated.

debris flow and rockfall activity over a width of about $1 \mathrm{~km}$ indicating that extended parts of rock and ice in the source wall and adjacent slopes had been in unstable conditions (A. Glazovsky, pers. communication). According to the data recorded by nearby seismic stations, the slope failures between July and September 2002 are not related to seismic activity.

To estimate the total mass loss from the Dzhimarai-khokh NNE wall, the QuickBird satellite images were analyzed together with oblique photographs from 2001 and earlier. The reconstruction of the former situation and measurements based on the QuickBird images are complex since the morphology and ice cover has strongly changed since September 2002. Volume estimates of the mass lost were done on the basis of geo-referenced satellite images (Fig. 3).

In the ice failure area, two zones were distinguished: an upper less inclined zone with ice sheared off to a depth of 10$15 \mathrm{~m}$, and a lower zone with deep-rupture failure $(30-40 \mathrm{~m})$ of hanging glaciers. The total ice volume lost is estimated between 8.5 and $13 \times 10^{6} \mathrm{~m}^{3}$. The rock failure zone is even more difficult to delineate, in particular the lower limit, since mass movements during and after the avalanche event blurred the former rock structures. Nevertheless, a main failure zone with a depth of 30-40 m could be identified as well as a secondary adjacent zone with a failure depth of 5-15 m. The total rock volume lost is estimated at $10-14 \times 10^{6} \mathrm{~m}^{3}$. The overall failure volume is thus between 18.5 and $27 \times 10^{6} \mathrm{~m}^{3}$, a value considerably higher than initial estimates suggested (less than ca. $10 \times 10^{6} \mathrm{~m}^{3}$ of ice/rock; Kotlyakov et al., 2004; Haeberli et al., 2005). The mass might, however, have partially failed already during days and weeks before the main event of 20 September 2002 (cf. Sect. 4.2).

\subsection{Assessment and interpretation}

Lithological and structural characteristics of the Dzhimaraikhokh NNE wall favor deep-seated slope failures. Analysis of the scar suggests that the initial failure was within the bedrock subsequently entraining a massive volume of ice from hanging glaciers. The steeply inclined daylighting bedrock layers in the lower part of the affected slope have likely exerted an important influence on the local stability conditions. In addition to the geology, the thermal aspects of the Dzhimarai-khokh NNE wall like permafrost occurrence and geothermal activity must be taken into account.

In fact, thermal conditions affecting ice and water within rock fissures have probably played a major influence. Bedrock stability in cold mountain areas can be especially low in warm or degrading permafrost (Davies et al., 2001; Gruber et al., 2004). Based on data from a former weather station near Karmadon, a mean annual air temperature (MAAT) of $-6 \pm 2^{\circ} \mathrm{C}$ at the lower and $-11 \pm 3^{\circ} \mathrm{C}$ at the upper end of the detachment zone are estimated (Haeberli et al., 2003). Bedrock surface temperatures in the detachment zone may thus be estimated at about -5 to $-10^{\circ} \mathrm{C}$, indicating bedrock conditions of cold permafrost. The thermal conditions, however, are complicated by the existence of hanging glaciers in the Dzhimarai-khokh NNE wall. Such steep ice bodies can induce significant thermal anomalies to the underlying bedrock since latent heat dissipation from percolating and refreezing meltwater at the firn surface often involves phase equilibrium temperature at the ice/bedrock interface behind the frozen ice front (Haeberli et al., 1997). Hence, it is reasonable to assume that the Dzhimarai-khokh failure zone was in a complex condition of relatively cold/thick permafrost combined with warm or unfrozen parts and meltwater flow in steeply inclined and heterogeneously permeable material favoring high and variable water pressures.

As mentioned above, the Kazabek area lies in a geothermally active zone. It has been argued whether geothermal activity influenced the Dzhimarai-khokh slope instability (Kotlyakov et al., 2004). The dust cloud visible on the QuickBird satellite image (Fig. 3) was believed to contain sulfur as reported by emergency personnel during a helicopter landing two days after the disaster. In addition to the hot springs around the Maili glacier tongue, indications of surfacing (possibly warm) water in the north-facing wall between Dzhimarai-khokh and Maili glacier were observed in spring 2003. In the slope failure zone, no indications of geothermal activity were recorded, neither during the 9-year monitoring period in the 1970ies (Kotlyakov et al., 2004) nor during summer 2003. Clear and unambiguous evidence from field observations at the site on the potential existence of hot springs and gas liberation in the slope failure zone is therefore missing presently.

Based on the available information, it cannot exactly be assessed how much rock/ice failed during precursor events and how much was detached during the main event of 20 September. The available photographic documents suggest that several millions of cubic meters of rock and ice failed 


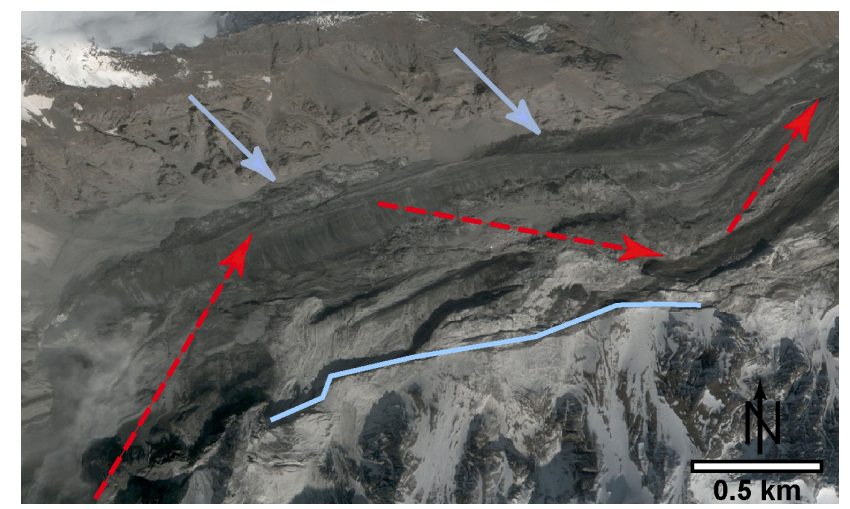

Fig. 4. QuickBird satellite image showing the remainings of the eroded Kolka glacier. Dashed red lines indicate impulse and main flow direction. Blue arrows point to the ice/debris deposits resulting from overflow of the left lateral moraine. The detachment of Kolka glacier at the right margin is indicated by a blue line.

during the weeks before the main event of 20 September. In particular the eastern slope area adjacent to the main detachment zone experienced frequent instability processes.

\section{Kolka glacier erosion}

\subsection{Observations}

The almost complete erosion of Kolka glacier was among the most extraordinary processes of the avalanche disaster. There is no comparable case documented worldwide so far. The erosive traces on the remaining glacier can be well recognized on the QuickBird satellite images (Fig. 4).

The pre-avalanche area of Kolka glacier of ca. $2.5 \mathrm{~km}^{2}$ as reconstructed from the satellite images is in correspondence with earlier measurements by Rototaev et al. (1983) or Kotlyakov et al. (2004). The area affected by erosion amounts to $2.35 \mathrm{~km}^{2}$ with a zone of $1.2 \mathrm{~km}^{2}$ showing erosion of several tens of meters deep. Based on satellite imagery and field observations, the erosion depth is estimated as 10$50 \mathrm{~m}$. Thus, the total ice mass eroded from Kolka glacier may be between 60 and $90 \times 10^{6} \mathrm{~m}^{3}$.

Field observations by mountaineers during the weeks prior to the avalanche (A. Glazovsky, pers. communication) indicated special hydraulic conditions of Kolka glacier (enhanced water pressure). Formation of lakes on and at the margin of the glacier was reported. Indications of subglacial water bodies were not observed but their existence cannot be excluded. Repeated ice and rock fall activity caused asymetric loading on the glacier and debris accumulation between mountain wall and glacier in a ramp-like form. It should also be noted that the summer 2002 in the northern Caucasus was characterized by high precipitation and melting rates of 1.5 to 2 times higher than average (Kotlyakov et al., 2004). This probably contributed to water saturated conditions at the glacial sediment bed and sub/englacial high water pressures. One picture showed unusual marginal crevassing on Kolka

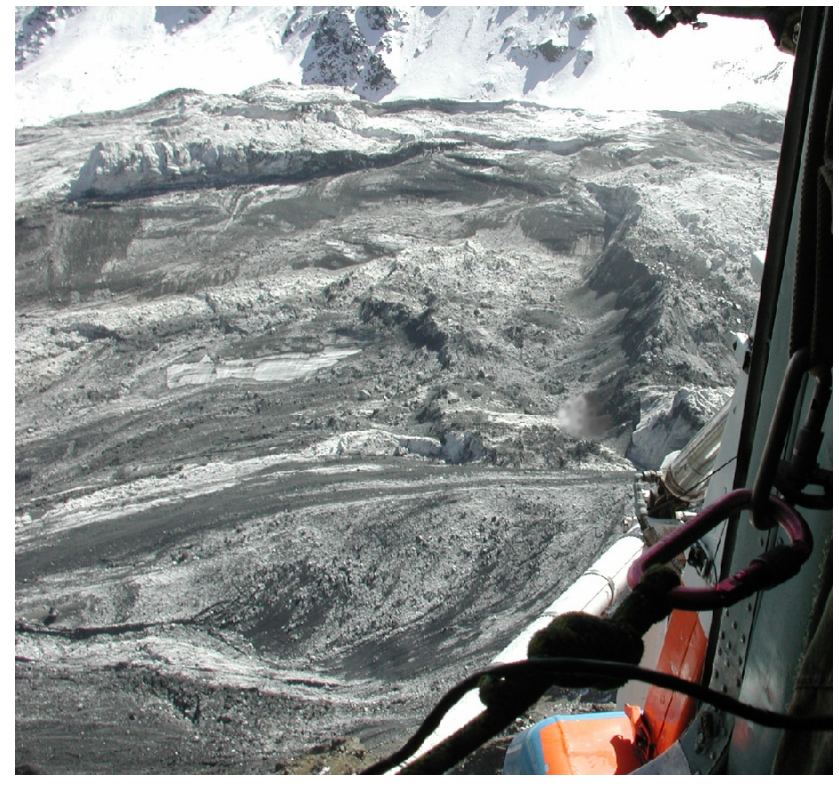

Fig. 5. Photograph of eroded Kolka glacier taken two days after the avalanche from the helicopter. The shattered and disrupted ice, and main and secondary flow lines can be recognized.

glacier but no clear indications of accelerated glacier flow were reported.

The erosion of Kolka glacier shows two striking features. First, the glacier ice appears to have been pushed towards the left lateral moraine with deposits behind the moraine due to overflow (Fig. 4). The flow was deflected at the moraine towards the main valley direction at an inflowing angle of about $45^{\circ}$ (according to the impact angle) and an outflowing angle of about $30^{\circ}$ to the horizontal. Secondly, on the opposite valley side a sharp line parallel to the foot of the Dzhimaraikhokh wall can be recognized along which the glacier was detached (Fig. 4).

The further erosion traces of Kolka glacier observed within the first week after the disaster (cf. Figs. 4 and 5) showed a rather chaotic pattern with a general flow direction towards the main valley as well as numerous cross-tracking flows. The erosive features, detachment zones and the shattered and crushed remaining ice are evidence of a massive impact. A comparable situation is not documented in the world and makes this case unique.

\subsection{Assessment and interpretation}

The extraordinary nature and dimension of the erosion of Kolka glacier gave room to various interpretations and speculations. Here, it is attempted to outline possible failure causes and to demonstrate by simple impact-, ice- and flowmechanical considerations which theories could be realistic and which ones rather not. Actually, it is crucial to understand the processes which led to the erosion of Kolka glacier since it is the key to the unusually large and destructive avalanche, and, thus, of essential importance for worldwide glacial hazard assessments. 


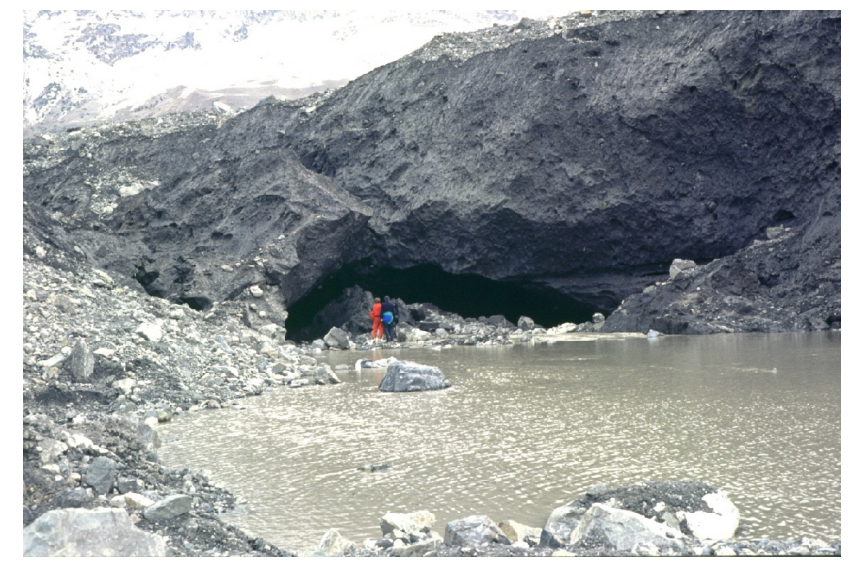

Fig. 6. Ice deposits at the Karmadon dam with a small temporary ice-marginal lake. The deposits are mostly composed by disrupted and re-compacted ice covered by a varyingly thick debris layer. Note the persons for scale (photo by C. Huggel, 8 May 2003).

The following hypotheses and related processes are evaluated in order to learn to which extent they can explain the failure of Kolka glacier:

1. Melting of the glacier by direct impact energy;

2. Melting of glacier ice and formation of avalanche by impact-related shock wave effects;

3. Instability within or/and at the base of Kolka glacier.

Hypothesis (1.) considers direct ice melt through transmission of energy by the falling rock/ice slide. Considering a failure mass of $20 \times 10^{6} \mathrm{~m}^{3}\left(10 \times 10^{6} \mathrm{~m}^{3}\right.$ ice and $10 \times 10^{6} \mathrm{~m}^{3}$ rock) and a drop height of $900 \mathrm{~m}$, a potential energy of $3.14 \times 10^{14} \mathrm{~kJ}$ is calculated. The impact energy on Kolka glacier could theoretically melt up to $1.1 \times 10^{6} \mathrm{~m}^{3}$ of ice (335 $\mathrm{kJ}$ per kg ice at $0^{\circ} \mathrm{C}$ necessary for melting). In reality, however, a considerable amount of energy is dissipated during fall and impact, so the actual amount of ice to be melted is likely less. Furthermore, in consideration of the precursor failure events (weeks and days before the main slope failure), it is reasonable to assume a smaller impact mass. A total maximum of $0.44 \times 10^{6} \mathrm{~m}^{3}$ of ice could be melted by, for instance, a mass of $8 \times 10^{6} \mathrm{~m}^{3}$. Therefore, hypothesis (1.) would only explain small volumes of removed ice.

Hypothesis (2.) relates to findings from crater impact research (typically meteorite impacts) (Dypvik et al., 2004). According to theoretical considerations, field observations and experimental studies shock waves can be produced by transformation of kinetic energy of the impacting mass (strong compression and deceleration of the impacting mass, and compression and acceleration of the target; Kieffer and Simonds, 1980). Impacts on icy targets involve disruption and shattering of ice (Arakawa, 1999; Benz and Asphaug, 1999). Such impacts are furthermore often accompanied by fluidization effects where the target material begins to flow even if it is rock or debris. Existence of water under the surface of the target greatly eases fluidization (Dence, 1971). A mechanism proposed for flow initiation is thereby acoustic fluidization of debris in relation with an acoustic field produced by shock waves (Melosh, 1987). In fact, it has often been observed that mud/debris flows are produced following meteorite impacts. The application of such theories to the Kolka case might appear somewhat exaggerated at first hand. Impact velocity may differ by about one order of magnitude between meteorite impacts (in the order of $1 \mathrm{~km} / \mathrm{s}$ ) and the slope failure at Dzhimarai-khokh (ca. $100 \mathrm{~m} / \mathrm{s}$ according to gravitational acceleration) but ice disruption processes have also been documented with impact velocities of $100-500 \mathrm{~m} / \mathrm{s}$ (Arakawa, 1999). Given the impact energy as the kinetic energy in the collision divided by target mass (Benz and Asphaug, 1999), the impact energy difference between the Kolka avalanche and meteorite impacts may thus be around one order of magnitude or more.

Notwithstanding, it has actually been observed that fluidization phenomena can take place in connection with impacts from large landslides on earth, e.g. during the 3 November, 2002, Alaska earthquake where several rockslides were triggered which themselves triggered mud/debris flows, partly also on glaciers but without entraining entire glaciers (Ebehart-Phillips et al., 2003). Hypothesis (2.) could help explaining the fluidization phenomena on Kolka glacier and the very strong acceleration of related flows. The photographs of Kolka glacier shortly after the disaster show remains of a highly shattered and disrupted ice surface (Fig. 5), which would fit the impact theory with associated disruption processes. The theory of ice disruption is also supported by the type of avalanche deposits found at the Karmadon ice dam. The deposits are mainly characterized by recompacted shattered ice particles while compact ice is much less found (Fig. 6). Mentioning the effects of water under the target surface is furthermore particularly interesting since it is likely that Kolka glacier was under high water pressure as outlined above.

This relates to hypothesis (3.) where an instability within and/or at the base of Kolka glacier is assumed. Such an instability is likely linked to the hydraulic condition of the glacier. High water pressure at the glacier base can significantly reduce the shear strength. In extreme conditions the glacier ice may be floating. Possible subglacial or englacial water bodies can further reduce the strength of ice. A hypothesis repeatedly discussed was the influence of possible volcanic and/or geothermal activity on the stability of Kolka glacier. Based on available data on a geothermal heat flux of ca. $80-100 \mathrm{~mW} / \mathrm{m}^{2}$ for the Kazbek area (Polyak et al., 2000), an annual melting of ca. $1 \mathrm{~cm}$ of ice can be derived. Higher heat flux values of $500-1000 \mathrm{~mW} / \mathrm{m}^{2}$ have been reported from other volcanic areas, particularly above magma chambers (e.g. Smith and Braile, 1994). Such a heat flux under Kolka glacier which would result in an annual melt of around $10 \mathrm{~cm}$ is still below the quantity that could affect the stability of Kolka glacier at its base. For comparison, ice melting related to glacier ablation is in the order of meters annually. 
Even though significant effects of geothermal heat flux on Kolka glacier destabilization can now be discarded, the role and causes of high basal water pressure should be investigated in more detail. Landslide and debris flow research shows that a water table is often a necessary condition to trigger mass collapse by increased pore water pressure under undrained conditions (Iverson, 1997). Water is an incompressible material and ensures a minimum hydrostatic pore pressure gradient which can account for a significant reduction of the granular shear stress (Legros, 2002). Such high water-pressure conditions may have prevailed with Kolka glacier prior to its failure. High and continuous liquid precipitation and strong melting during summer 2002 could have resulted in a significant increase of subglacial water, causing an increase of pore pressure due to a predominantly impermeable sediment bed. The effect would be a reduction of shear stress, or even fluidization or floatation at the glacier base. On account of the moderate slope of Kolka glacier and its surrounding topography, a spontaneous collapse and flow formation is still unlikely under these conditions. However, a major force acting on the glacier from a high-energy impact could be sufficient to initiate the flow. The unstable conditions of Kolka glacier prior to its failure are probably the reason why other rock or debris avalanches of comparable dimensions impacting glaciers have not caused significant glacier erosion. In fact, several rock avalanches on glaciers are documented worldwide, for instance the rock avalanche on Sherman glacier, Alaska, in 1964 (McSaveney, 1978), the Iliamna debris avalanches on Red glacier, Alaska, in the 1990ies (Waythomas et al., 2000), the rock avalanche on Black Rapids glacier caused by the 3 November 2002, Alaska earthquake (Ebehart-Phillips et al., 2003) or a number of rock avalanches in British Columbia, Canada (Evans and Clague, 1988), but none of them showed massive erosion of the glacier affected.

Kotlyakov et al. (2002) and Desinov (2004) believe that the high water input to the glacier in combination with the overload of debris by continuous rock/ice fall in late summer 2002 was sufficient to cause failure of Kolka glacier without any major rock fall impact as a trigger. The instability of Kolka glacier was also suggested to be linked to its surge activity (Kotlyakov et al., 2004; Petrakov et al., 2004). The last surge of Kolka glacier dated from 1969/1970 (Rototaev et al., 1983). During this surge, the heavily crevassed glacier advanced with typical velocities of meters to decameters per day over a total distance of $4.5 \mathrm{~km}$ without loosing connection to its accumulation area (Hoinkes, 1972). Avalanche flow velocities, in constrast, were decameters per second. A similar but smaller avalanche event than 2002 happened in 1902 (and probably in 1835 as well; Popovnin et al., 2003). The event, documented by Poggenpohl (1905), involved a rock/ice slide from the Dzhimarai-khokh NNE wall with a travel distance of $12 \mathrm{~km}$. Flow height was about $100 \mathrm{~m}$ and average flow velocity ca. $50 \mathrm{~m} / \mathrm{s}$. Poggenpohl (1905) did not report any destructive effects or instability of Kolka glacier during these events. Kotlyakov et al. (2004), however, stated that a glacier surge had started in 2002 some weeks before the

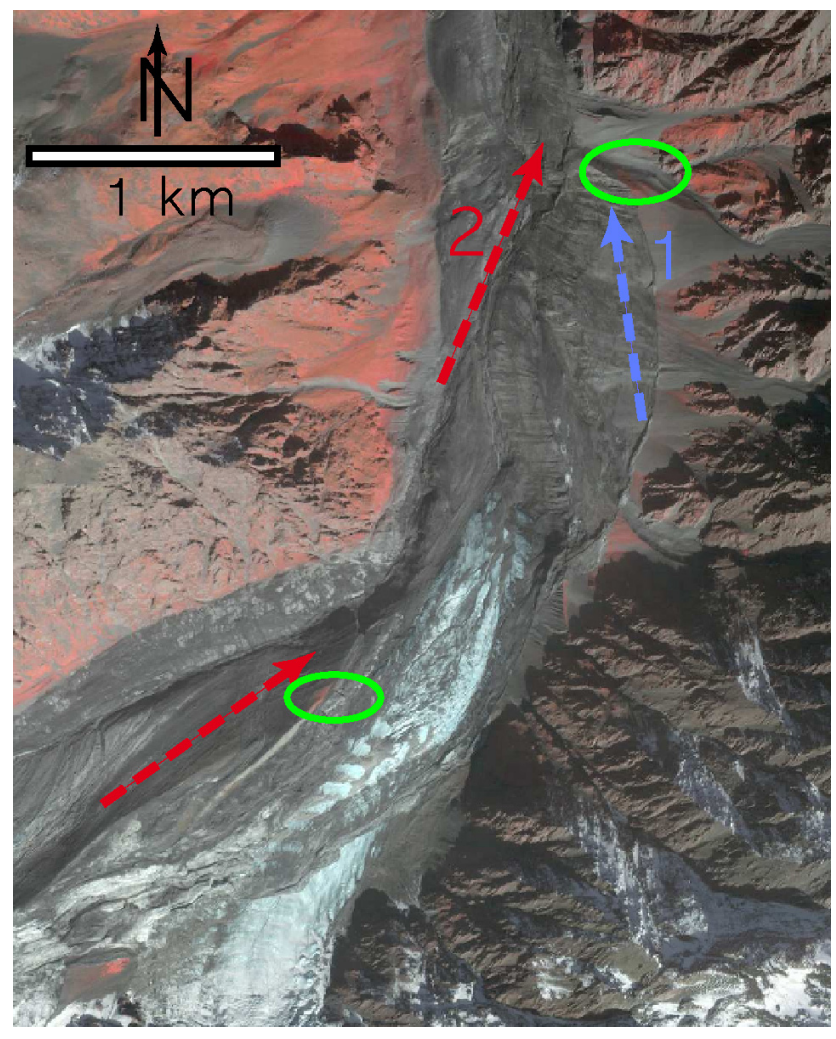

Fig. 7. Near-infrared QuickBird image of the superelevation zone. Arrows indicate avalanche flow directions as visible on the image. The blue arrow represents the first more liquid flow while the red one points to deposits from the second flow. The green circles are evidence of unaffected vegetation (in red), the upper one indicating overjump processes.

avalanche even though in mid-August 2002 no indications for such a process could be observed. The 1969/1970 classical surge clearly differed from the 2002 avalanche (though the 2002 event is often referred to as "surge" in Russia) by extreme longitudinal extension (1969/1970) versus complete detachment of the glacier (2002). The surge behaviour shows, however, that the debris-covered Kolka glacier is able to decouple from its (sediment) bed.

After the discussion of the feasibility of hypotheses (1.) to (3.) it is concluded that hypothesis (1.) can certainly not explain the full failure of Kolka glacier and that hypothesis (3.) provides an important explanation. It is likely that processes related to all three hypotheses were involved during the event.

\section{Avalanche dynamics}

\subsection{Observations}

Observation in the field and on QuickBird images showed two different flow patterns starting from Kolka glacier (Figs. 7 and 8). The first flow runs along the right glacier margin parallel to the northern slope linking Dzhimarai- 


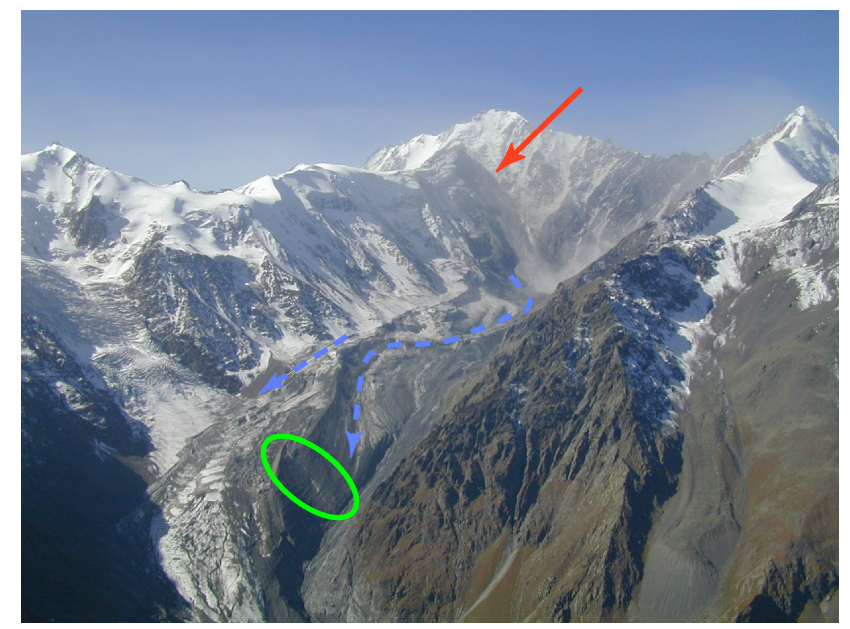

Fig. 8. Photograph showing Dzhimarai-khokh and the initial slope failure zone (red arrow). The two main flows of the avalanche starting from Kolka glacier and crossing the tongue of Maili glacier are indicated by the dashed blue arrow. The green circle indicates a secondary flow from the liquid flow area to the main flow zone (cf. text) (photo by I. Galushkin, 22 September 2002).

khokh and Kasbek mountain. Then it runs straight downstream and crosses Maili glacier at an altitude of about $2800 \mathrm{~m}$ a.s.l. A striking feature is the straight line where Kolka glacier was disrupted leaving a scar of 10-30 m height. The erosional force of this first mass flow must have been less than the one of the second flow, however, since the overflown Maili glacier remains intact (Fig. 8). In fact, the flow structures around Maili glacier suggest a liquid flow with a sediment concentration probably not higher than ca. 30-40\% by volume, which would correspond to a hyperconcentrated flow (Pierson and Costa, 1987).

The second flow had quite distinct characteristics and started as a continuation of the NNE wall of Dzhimaraikhokh hitting Kolka glacier in a $45^{\circ}$ angle to the horizontal. The flow was deflected at the left lateral moraine of Kolka glacier and then diverted to the right valley margin. There it almost met the upper straight erosion line and made a strong left turn (Fig. 4). Ice/debris deposits on the airside of the lateral Kolka moraine at the point of flow deflection indicate that the impulse was large enough to overflow the moraine. The left lateral moraine was also overflown some hundred meters further downstream at the lower end of Kolka glacier. Further downstream, the main flow then hit the left lateral rockwall at an angle of $30^{\circ}$ and produced a superelevation of ca. $150 \mathrm{~m}$. The main flow was constrained within the Kolka gorge which then makes a sharp left turn to the north. The QuickBird images at this point show very well erosional streamline structures and thus the direction of the flow (Fig. 7). Interestingly, the middle part of the left lateral moraine of Maili glacier remained unaffected as evidence from vegetation cover on the QuickBird images indicates (Fig. 7). In comparison with the first more liquid flow, the second one showed a higher solid concentration and may have been rather an avalanche sliding process of massive volumes of ice.

The two main mass flows, separated by only a few seconds and probably triggered by two successive avalanche impacts, crossed each other in the area of the major superelevation at the north-bound turn of the main valley. While the first more liquid flow traveled along the right valley margin and produced this spectacular superelevation, the second flow following the left side run up the lower part of the superelevation. Corresponding deposits visible in the QuickBird images clearly show that the right-margin flow was followed by the left flow (Fig. 7). At the downstream end of the superelevation, unaffected vegetation is evidence of overjumping by the first flow of the avalanche, thus indicating very high flow speeds (Fig. 7).

The avalanche then continued along the Genaldon valley. The flow depth was 60 to $150 \mathrm{~m}$ with repeated superelevations of up to $200 \mathrm{~m}$. The observed superelevations imply a swing-like movement of the slide suggesting the movement of a compact mass through the fairly straight Genaldon valley (Figs. 1 and 9). The occurrence of parallel superelevations on opposite valley flanks confirms the existence of at least two flows. Similar as at the superelevation of the main valley bend, secondary flow deposits in other superelevations can be recognized on the satellite image (Fig. 9). Again, the first flow caused the superelevation while the second one ran across the superelevation in an upward movement.

The trim line along the Genaldon valley is mostly a sharp line with a small upwards splash zone of about $10-30 \mathrm{~m}$. Field observations together with analysis of the QuickBird images showed skipped shrubs and small trees in this zone, as well as the deposition of fine-grained debris to $30 \mathrm{~cm}$ boulders. Indications of a high-pressure (dust) waves are missing.

At the widening of the valley near Karmadon, flow depth and velocity decreased and flow spreading took place. The main mass of the slide was eventually stopped at the entrance of the narrow Genaldon Gorge forming a huge ice/debris dam. According to geodetic measurements, the ice/debris dam had a volume of $115 \times 10^{6} \mathrm{~m}^{3}$. The downstream part of the dam was charaterized by a higher content of compact ice and a thinner debris layer whereas the upstream part of the dam, i.e. the avalanche "tail", showed mainly disrupted and recompacted ice and a larger amount of surficial debris (Fig. 6). While the main ice masses were stopped, water and fine sediment from the first flow part, and possibly also expelled as a consequence of the extreme compression of the fast sliding main flow mass, caused the formation of a distal mudflow, traveling down the gorge, joining the Giseldon river and eventually running out at a distance of about $15 \mathrm{~km}$ from the gorge entrance. Reports related to the temporal passage of the avalanche and the distal mudflow indicate an immediate initiation of the mudflow during avalanche stopping and deposition at the Genaldon gorge entrance. This assumption is furthermore supported by the observation of deposits indicating a high runup at the gorge entrance which were followed continuously by large flow heights $(20-50 \mathrm{~m})$ further 


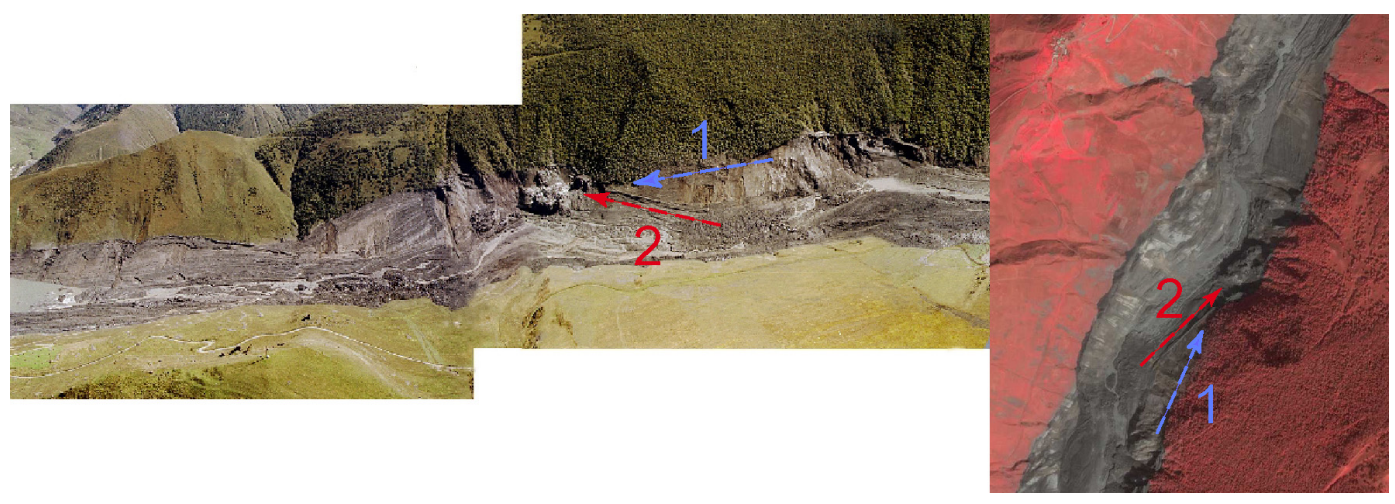

Fig. 9. Photograph taken from the helicopter and the corresponding QuickBird near-infrared image showing the avalanche transit zone with repeated superelevations, shortly before the ice dam at Karmadon. The arrows depict the flow direction of the two avalanche surges (flow 1 in blue is followed by flow 2 in red; note the ice deposits from flow 2).

Table 1. Values of the angle of reach $\alpha$ for different travel distances of the Kolka/Karmadon avalanche and distal mudflow.

\begin{tabular}{ccc}
\hline Avalanche/mudflow start - end point & $\tan \alpha$ & $\alpha$ \\
\hline NNE face - Karmadon ice dam & 0.15 & $8.5^{\circ}$ \\
Kolka glacier - Karmadon ice dam & 0.11 & $6.4^{\circ}$ \\
NNE face - distal mudflow deposits & 0.10 & $5.9^{\circ}$ \\
Kolka glacier - distal mudflow deposits & 0.08 & $4.6^{\circ}$ \\
NNE face - Karmadon ice dam (centre of mass) & 0.12 & $7.0^{\circ}$
\end{tabular}

downstream, thus suggesting a direct continuation of the first more liquid flow part into the distal mudflow. Deposits in the mudflow area mostly consisted of mud, sand, gravel and wooden debris. Ice deposits were not observed. Based on mapping of the QuickBird images, the total mudflow volume was about $4-6 \times 10^{6} \mathrm{~m}^{3}$.

The mobility of landslides or avalanches is often expressed by their angle of reach (also termed Fahrböschung or average slope), i.e. the angle $\alpha$ of the line connecting the avalanche starting point with the distal margin of the deposit (Heim, 1932). The tangent of the angle of reach has later been defined as the coefficient of friction of the surface between sliding mass and ground (Shreve, 1968; Scheidegger, 1973; equivalent to the ratio of the vertical drop height $\mathrm{H}$ and the horizontal travel distance $L$ ). It has, however, been argued that the concept of coefficient of friction is only valid for linking the centre of mass of slide source and deposit (Hsü, 1975). Yet, in statistical analyses of landslide and avalanche geometry, the maximum travel length vs. drop height is more commonly used and more relevant for hazard assessments than the centre of mass. Description of the geometry of the Kolka avalanche should take into account two different starting points, i.e. the point of initial slope failure at the NNE face of Dzhimarai-khokh and Kolka glacier. The distinction is of importance for comparison with other events, for the derivation of the appropriate coefficient of friction, and in view of hazard evaluation. The Fahrböschung concept typically takes into account only the geometry of the main avalanche path. However, for practical reasons of hazards assessment and because the liquid flow part of the avalanche directly evolved into the distal mudflow, the angle of reach is given both for the trajectory down to the avalanche deposits at Karmadon and to the mudflow deposits near Gisel (Table 1).

\subsection{Assessment and interpretation}

Based on the analysis of QuickBird satellite images, aerial oblique photographs, and repeated field observations, avalanche formation and dynamics were reconstructed as follows. The two overflows of the left lateral Kolka moraine show that Kolka glacier must have been pushed to the left side by a major impact from the Dzhimarai-khokh NNE wall. Due to this impact and related traction forces, the ice was disrupted at the right glacier margin. After having been deflected to the right at the left-lateral moraine, the flow turned to the left again and carried the main part of the ice/debris mass downstream. Another more liquid flow travelled down the right valley margin at a higher speed. The origin of the water cannot be clearly determined yet but may be from friction-related ice melt during the initial ice/rockfall and from water stored on, in and under Kolka glacier. Thermo-mechanical calculations indicate that only 70000 to $200000 \mathrm{~m}^{3}$ of water may stem from the initial fall (based on an actual drop height of $900 \mathrm{~m}$, a volume-independent drop height of $37000 \mathrm{~m}$ for complete ice melt (Körner, 1983), an energy efficiency gradient of 0.4 and a mass volume of 8 and 
$20 \times 10^{6} \mathrm{~m}^{3}$, respectively). Therefore, it is likely that Kolka glacier had already contained a large amount of water. The temporal separation of the two main flows must have been in the order of seconds. Figure 8 shows deposits of a smaller secondary ice/debris mass which flowed from the liquid flow zone into the main flow area after passage of the main mass. Since the liquid flow was temporally the first one as evidence from the superelevation shows, this small secondary flow must have originated from the tail of the liquid flow, and the main avalanche must have been only seconds behind the liquid flow.

Though documents from comparable events are virtually non-existing, it appears that different flows of varying liquid/solid concentration could be a common characteristic of large ice avalanches. During the 1974 surge of Didal glacier (Central Asia), for instance, an ice avalanche with a volume of about $1.5 \times 10^{6} \mathrm{~m}^{3}$ formed at the glacier front, and three different flow waves with varying solid concentration were observed (written communication by A. Yablokow to J. Schneider, Vienna).

Velocity estimates for the liquid, hyperconcentrated flow at the main superelevation are based on basic hydraulic considerations (Chow, 1959; Evans and Clague, 2001):

$v=\sqrt{\frac{g \cdot d \cdot r}{b}}$,

where $v=$ flow velocity, $g=$ gravitational acceleration, $d=$ superelevation, $r=$ centreline radius of curvature, $b=$ channel width, yielding a maximum of $v=70$ to $90 \mathrm{~m} / \mathrm{s}$ with $r=1500 \mathrm{~m}, b=600 \mathrm{~m}$ and $d=200-250 \mathrm{~m}$.

The unaffected vegetation in the downstream area of the superelevation also confirms such high flow velocities (overjumping effects, Fig. 7). The average flow velocity of the avalanche from Kolka glacier down to Karmadon was estimated using a seismic record from the impacting mass on Kolka glacier and the disruption of the power lines at Karmadon (Haeberli et al., 2005). The resulting mean velocity of 50 to $80 \mathrm{~m} / \mathrm{s}$ is enormous considering the moderate slope of the Genaldon valley from the Maili glacier tongue down to Karmadon (ca. $5-6^{\circ}$ ). Similarly high velocities of 50 to $60 \mathrm{~m} / \mathrm{s}$ were reported from rock slides but on much steeper slopes (Evans and Clague, 2001). Debris flows on steep volcanic flanks have reached velocities of up to $40 \mathrm{~m} / \mathrm{s}$ (Pierson, 1995).

The extreme acceleration of the main glacier mass over a distance of only about $4-5 \mathrm{~km}$ is also highly unusual. Explanations for long-runout slides and avalanches include air, water and acoustic fluidization effects (Shreve, 1968; Melosh, 1987; Voight and Sousa, 1994; Legros, 2002). An interstitial fluid can reduce solid friction by supporting particles and reducing the normal granular stress. If the fluid pressure gradient becomes equal to lithostatic, the whole load of the solid material is supported by the fluid, and solid friction basically decreases to zero (Legros, 2002). Observations of the avalanche track suggest a significant amount of water being involved in the avalanche. Simulations of the distal mudflow using FLO-2D (O'Brien et al., 1993) yielded a sed- iment concentration of ca. $40 \%$ and thus a total amount of water of $2-4 \times 10^{6} \mathrm{~m}^{3}$. It is thereby assumed that the water involved in the avalanche was largely transferred to the subsequent mudflow. The incompressibility of water facilitates attaining lithostatic pressure, and thus, a few millions of cubic meters of water should be sufficient to fluidize a solid mass of $60-80 \times 10^{6} \mathrm{~m}^{3}$ (cf. Legros, 2002) though the liquid concentration in relation to the main avalanche mass was rather low (roughly 10\%). Recent experimental work on pore pressure generation in debris flows suggests that a net downward movement of the debris is required to maintain high pore pressures (Iverson, 1997; Major, 2000; Iverson and Denlinger, 2001). The Kolka avalanche is supposed to have maintained high pore pressures all along the avalanche track even though deposition at the base was rarely observed, at least in the upper and middle part of the track. This may be due to a continuous supply of water at the bottom of the avalanche by frictional melting of ice which enabled maintaining high pore pressures.

In order to evaluate the enormous acceleration from Kolka glacier to the first site of large superelevation, a simple friction model was applied.

$F_{a}=F_{e}-F_{f}$,

where $F_{e}$ is the effective downward force, $F_{a}$ the downward force parallel to the surface slope due to gravitational acceleration and $F_{f}$ the friction force. $F_{f}$ can be expressed as

$F_{f}=\mu-N$,

where $\mu$ is the friction coefficient equal to $\tan \alpha$ and $N$ the normal stress.

According to Newton's second law, the resulting acceleration a is then

$a=\frac{F_{e}}{m}$

with $m=$ avalanche mass.

Assuming an avalanche volume of $60 \times 10^{6} \mathrm{~m}^{3}$, the density of ice $\rho_{\text {ice }}=850 \mathrm{~kg} / \mathrm{m}^{3}, \tan \alpha=0.11$ (cf. Table 1) and the surface slope $\beta=10^{\circ}$, a is equal to $0.64 \mathrm{~m} / \mathrm{s}^{2}$. Assuming furthermore an acceleration time of $100 \mathrm{~s}$ until the point of superelevation, the velocity attained is $64 \mathrm{~m} / \mathrm{s}$, and thus a velocity at the lower range of the one estimated above.

These considerations show that, based on the assumption of a constant coefficient of friction from Kolka glacier to the Karmadon ice dam, the acceleration of the ice mass from zero velocity at Kolka glacier to a velocity in the range as observed at the superelevation can theoretically be reproduced. The friction model does not consider additional acceleration due to the initiating impact force. Hence, the velocity would result higher than calculated and may be closer to a velocity of $90 \mathrm{~m} / \mathrm{s}$ as reconstructed.

The mobility of the Kolka avalanche is at the upper limit for known rock/ice avalanches. The second largest documented rock/ice avalanche after Kolka is the Huascarán event in 1970 which showed a coefficient of friction of 0.24 with a total mass of $50-70 \times 10^{6} \mathrm{~m}^{3}$ (Plafker and Ericksen, 1978; 


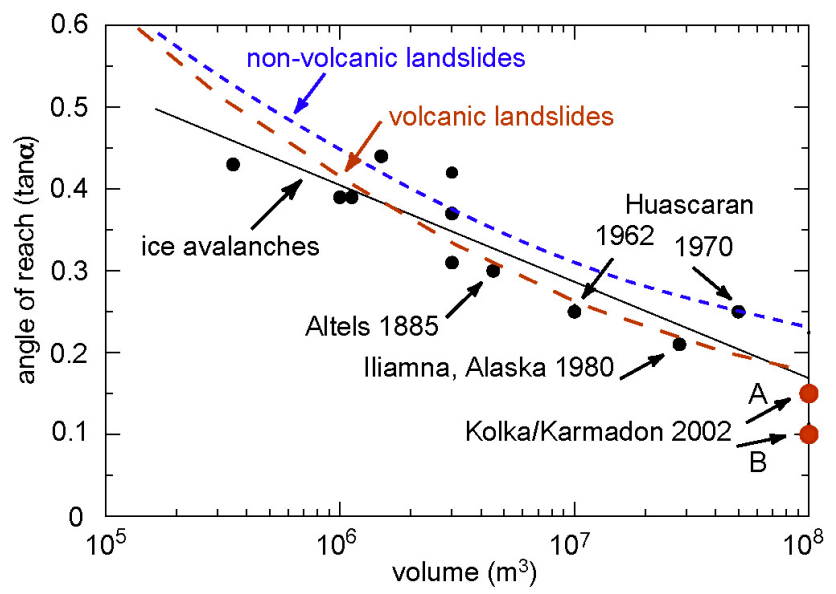

Fig. 10. Bivariate plot of volume versus reach angle of major ice avalanches. The black regression line represents the relationship: $\tan \alpha=1.111-0.118 \log (\mathrm{V})$ (Huggel et al., 2004). Regression lines for volcanic and non-volcanic landslides from Legros (2002) are shown in red and blue. For the Kolka/Karmadon avalanche, the two data points refer to the angle of reach based on a travel distance to the ice dam (A) and to the distal mudflow deposits (B) (data from Huggel et al. (2004) and this study). Note that published values of $\alpha$ or ratios of $\mathrm{H} / \mathrm{L}$ of landslides usually do not include the runout of distal mudflows or lahars.

Körner, 1983). A considerable number of empirical relationships have been proposed to derive the angle of reach from the volume of different types of ice and rock avalanches, landslides or debris flows (e.g. Scheidegger, 1973; Evans and Clague, 1988; Corominas, 1996; Rickenmann, 1999; Legros, 2002; Huggel et al., 2004). Corominas (1996) has thereby shown that the angle of reach is essentially dependent on the mass volume and not on the fall height. The reach angle of the Kolka event is at the lower end when compared with corresponding relationships (best power-law/log fits) for ice avalanches (Alean, 1985; Huggel et al., 2004) or volcanic landslides (Legros, 2002), and considerably overestimated by relationships for non-volcanic landslides (Legros, 2002) (Fig. 10). The Kolka avalanche actually better fits to corresponding relationships for debris flows or lahars (Rickenmann, 1999), in particular when looking at the reach angle for the trajectory from Kolka glacier to the distal end of the mudflow. In fact, a comparison with volcanic landslides which typically evolve into lahars may be a feasible analogy for the Kolka avalanche in terms of mobility. Nevertheless, the processes of movement observed at Kolka/Karmadon have rarely been described so far. Therefore, it is difficult to assign the Kolka avalanche to established classifications of sediment-water flows or landslides (Pierson and Costa, 1987; Hungr et al., 2001). For example, velocities in the order of $100 \mathrm{~m} / \mathrm{s}$ have been described for (fluidized) granular flows but seldom for more liquid slurry flows.

Field evidence at Kolka/Karmadon such as the relative position, and depositional characteristics, of superelevations suggests the movement of a large compact mass, immedi- ately behind a more liquid flow. The first liquid flow had characteristics similar to a hyperconcentrated flow whereas the second flow part probably consisted of a large ice mass moving on a basal water layer (ca. 10\% water concentration). The conservation of very high velocities over a long distance with moderate inclination is one of the most spectacular features of the Kolka avalanche. As outlined above, fluidization effects at the base of the moving mass with high pore pressures, and a continuous supply of water due to frictional melting of ice, probably have played a significant role. Still, in detail the mechanics of the Kolka avalanche are not understood. The case, however, can serve as an important illustration for advancing our knowledge on fast-moving, longrunout ice and rock avalanches, and, thus, for improving corresponding hazard assessments.

\section{Implications for worldwide glacial hazard assess- ments}

In view of the rare dimensions and the extraordinary processes of the Kolka disaster, it was clear from the beginning that as much as possible had to be learned from this case where it became reality what most specialists had considered as impossible so far, i.e. the failure of virtually an entire valley-type glacier. Therefore, one of the objectives of the project was to draw conclusions of the Kolka disaster for the European Alps and generally for global glacierized highmountain regions. Based on the analysis of the event, the following implications split in three thematic aspects were identified:

7.1 Slope instability in large glacierized high-mountain walls

- Large and steep rock slopes in permafrost conditions can experience slope instabilities, in particular in relation with permafrost degradation processes. Hanging glaciers in such rockwalls are often at the stability limit and introduce complex ground thermal conditions. Especially critical situations can arise in glacierized rockwalls in permafrost conditions which are usually in a delicate equilibrium and are susceptible to system disturbance such as short-term (e.g. seasonally high precipitation) or long-term (e.g. atmospheric warming) climatic variation or change.

- The geological structure of the high-mountain wall may not necessarily be an immediate trigger factor of slope instability but determines the susceptibility to failure. Daylighting of steeply inclined layers makes a high mountain wall particularly prone to large slope failures.

- Geothermal activity in glacierized steep permafrost rockwalls can induce important thermal anomalies and effectively destabilize the slope by melting and related change of stress. 


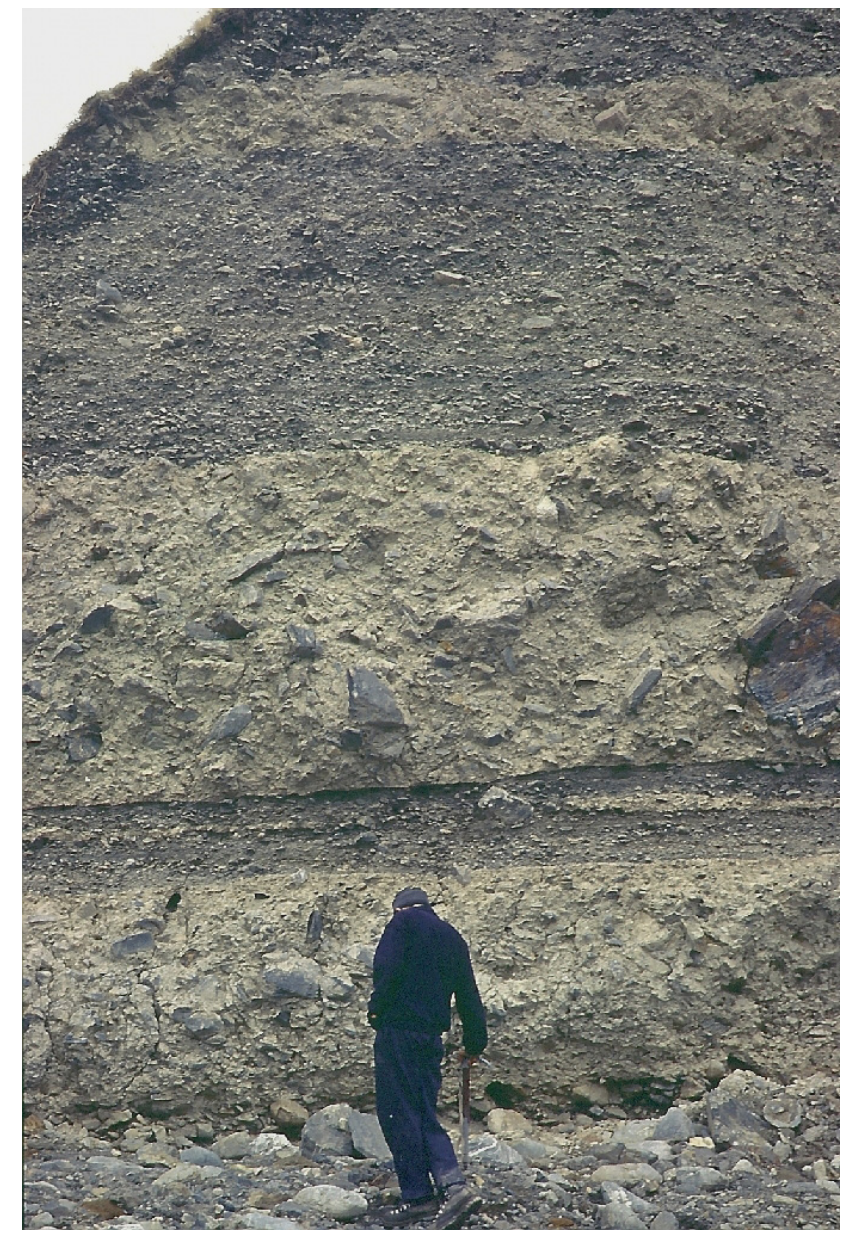

Fig. 11. Deposits of at least two major mass movement processes resembling rock avalanches intersected by fluvial sediment accumulations. The deposits were found at the upstream end of the Karmadon ice dam (photo by C. Huggel, 8 May 2003).

- Given adverse geological conditions, large glacierized mountain walls have the potential for high-magnitude failures. This may appear a trivial finding but implications should seriously be taken into account for hazard assessment even though the probability of occurrence of large events is relatively small.

- Large slope failures are often preceded by smaller precursor events. A regular monitoring of potentially hazardous mountain walls can therefore contribute to mitigate disasters. Monitoring is also important in view of the rapid climatic change and related change of slope stability.

\subsection{Glacier instability}

- Glaciers which can develop englacial or subglacial instabilities and can be hit by large impacting mass movements have the potential to fail, and thus for large disasters. Glaciers at the toe of large glacierized mountain walls are common phenomena in many mountain regions around the world. This particular conclusion may therefore imply a revision of views on glacier stability in such situations.

- The processes that may cause en/subglacially unstable conditions and may make glaciers prone to failure are complex and not well understood. It is, however, highly probable that a strong increase in subglacial water pressure is a critical if not the determinant factor for glacier instability (similar to the one experienced with Kolka glacier).

- A sediment bed of the glacier could possibly be a "sinequa-non" condition for such instabilities in moderately inclined glaciers. A saturated sediment bed with high water pressure may have the characteristics of a "soft soap".

- Heat fluxes related to geothermal activity are usually not sufficient to produce subglacial water pressures which enable destabilization of a valley-type glacier. An exception may be volcanic eruptions (e.g. Gjálp, Vatnajökull, Iceland; Gudmundsson et al., 2004). The situation is different with steep (hanging) glaciers: additional melt at the glacier base from geothermal activity can result in extreme hydraulic gradients in polythermal ice causing stress changes and disturb the delicate equilibrium possibly leading to glacier failure.

- In consideration that Kolka glacier is the only documented induced failure case of a moderately inclined valley-type glacier, it is not possible to indicate a minimum or maximum glacier size which allows complete failure or erosion by impacts. Whether failure occurs depends on impact energy, efficiency of energy transfer, and geometry and stability conditions of the glacier. Glaciers significantly larger than Kolka glacier (i.e. larger than about $10 \mathrm{~km}^{2}$ ) would probably require an enormous impact energy in order to fail. Impacts with such energies have very low probabilities of occurrence. Partial failure associated with smaller impacts, however, could not be excluded.

- Glaciers with historical surge behavior may be more susceptible to large instabilities. However, since Kolka glacier was not in a surge phase at the time of the disaster, an unambiguous relation between surge, instability and failure cannot be proposed.

\subsection{Avalanche processes}

- Avalanches involving a volume of ice in the order of $10^{8} \mathrm{~m}^{3}$ are extremely rare. A similar event is historically not documented worldwide and derivation of such events from geological records (deposits) is usually not possible since deposited ice is typically not preserved more than a few years to decades. Yet, in Karmadon deposits of past mass movements were found at the upstream end of the present ice dam (Fig. 11). Fluvial deposits alternate with deposits resembling rock avalanche 
processes. More detailed investigations concerning origin and age of the deposits are underway. Meanwhile, such field evidence may be an indication that similar events as the 2002 avalanche also happened in the past (Kotlyakov et al., 2002). Likewise, studies in other regions of the Caucasus have revealed evidence of similar mass movement types in the Holocene (Bogatikov et al., 1998; Bogatikov et al., 2003).

- Entrainment of massive volumes of ice may result in processes that enable long-runout and high-velocity avalanches. Since such events are very rare, the related processes are not well understood although theoretical considerations have been made.

- In avalanches with large volumes of ice, granular friction can effectively be reduced by melting of ice and possibly associated fluidization effects and by reduced friction through sliding of ice. The travel distance of such avalanches may be at the upper limit of statistical volume vs. angle-of-reach relationships of rock/ice avalanches and landslides, considering only the main avalanche path (without any distal mudflows). Assessment of hazards in terms of area potentially affected is therefore possible if a critical situation is identified. The crucial point thereby is in-advance assessment of the probable failure volume, particularly regarding glacier entrainment. A practical approach in such a case is the definition of different scenarios.

- Ice avalanches have the potential for flow transformation, mainly by melted ice and debris entrainment. The distal hazard zone may therefore be considerably enlarged when accounting for secondary debris flow or mudflow processes.

\section{Evaluation of QuickBird imagery}

QuickBird is currently the top solution among satellite sensors in terms of spatial resolution. Corresponding applications can be regarded representative for other very-high resolution sensors such as IKONOS or Orbview-3, and, to some extent, SPOT-5 (2.5 m ground resolution). So far, more conventional satellite sensors (e.g. Landsat-5/7, SPOT$3 / 4$, ASTER) have been used for assessment of glacial hazards. Application examples are detection of hazardous glacial lakes (Wessels et al., 2002; Huggel et al., 2002), identification of ice avalanche prone glaciers (Salzmann et al., 2004), or mass movement modeling based on ASTERderived DEMs (Huggel et al., 2003; Kääb et al., 2003b). The spatial resolution of 15-30 m makes ASTER and Landsat7 suitable for regional applications covering areas of $10^{2}$ $10^{4} \mathrm{~km}^{2}$. In view of the spatial resolution and related acquisition costs, QuickBird images are clearly more adequate for local studies.

This study has shown that QuickBird images facilitate analyses that previously have not been possible with satellite imagery. Demonstrated applications include estimates of avalanche dimension, analysis of flow formation and dynamics, and avalanche, ice dam and mudflow mapping. This kind of study may also be achieved using aerial photography. However, QuickBird imagery is superior to aerial photography in terms of full digital data processing and multispectral band capabilities. Furthermore, it can be acquired from virtually any location on earth whereas up-to-date aerial photography may not be available, or acquisition is prevented due to political or military restrictions, difficult logistics or remoteness of the target location. QuickBird images can usually become available a few days after a disaster if weather conditions allow. QuickBird can therefore also be employed for disaster management and response by evaluation of damages or identification of access routes to the disaster area, which necessarily requires very-high resolution data. If, on the other hand, repeated acquisition of images is needed, e.g. for continuous hazard monitoring, or for pre-/post-event analyses, ASTER may be the more appropriate tool (Kääb et al., 2003a). In most cases, QuickBird is too expensive for acquisition of more than one image sample.

In combination with digital terrain data, QuickBird can be used for quantitative measurements in three dimensions, e.g. for detailed slope measurements such as demonstrated in the present contribution. Numerical mass movement modeling is another example for which QuickBird imagery has been applied during the studies of the Kolka/Karmadon avalanche and mudflow (cf. Swartz et al., 2004).

\section{Conclusions}

It has been demonstrated that several aspects of the Kolka avalanche were extraordinary (large ice volume, high flow velocity, long travel distance) if not unique (entrainment of Kolka glacier). The erosion of Kolka glacier is not yet well understood but reasonable assumptions suggest that a highenergy impact on the glacier in critical conditions of stability (high en/subglacial water pressure) occurred. The process of the Kolka avalanche motion is instructive and important for the understanding of the mobility of large-volume ice avalanches by strongly reduced friction and fluidization processes moving in different flow waves. It has been shown that large high-mountain walls in permafrost conditions have the potential for large failures depending on the susceptibility determined by geological factors. If a potentially unstable glacier is within the range of impact, a large disaster cannot be excluded. Continuous monitoring of such potentially critical situations is of crucial importance.

Beyond the process analysis, it was an objective of this paper to evaluate the potential of QuickBird satellite images for assessment of glacial and high-mountain hazards. QuickBird is thereby representative for new satellite systems such as IKONOS or Orbview-3. The use of QuickBird imagery has been demonstrated for estimates of avalanche dimension, analysis of flow formation and dynamics, and for topographic measurements in combination with digital terrain data. Though not specifically described here, Quick- 
Bird satellite images can furthermore be applied for disaster management and response. A limiting factor with QuickBird (and generally very-high resolution satellite data) is the high cost of image acquisition. Even though this data has virtually not yet been applied for assessment of high-mountain hazards so far, this study suggests that the large potential of such images will trigger an increasing number of applications in the future.

Acknowledgements. The project within which this study was carried out was directed and financed by the Swiss Agency for Development and Cooperation, Humanitarian Aid. Georeferencing of the QuickBird images by Nadine Salzmann is highly appreciated. We are very grateful for the valuable work and assistance by L. Pigareva, and continuous support by D. Dreyer. Field support by North Ossetian mountain guides, Emercom (Ministry of Emergency Situations), and discussions with A. Misetov as well as with M. Swartz and B. McArdell are also acknowledged. The paper much benefited from discussions at a workshop on the Kolka/Karmadon disaster in June 2004. Because of securitymotivated access restrictions to the region due to armed fighting, a parallel workshop with international experts had to be held in Moscow instead of Vladikavkas, North Ossetia, where the main symposium was organized. We particularly appreciate the discussions with workshop participants M. Chiarle (Italy), J. Hanisch (Germany), J. Schneider (Austria), S. Chernomorets, A. Gurbanov, A. Strom and O. Tutubalina (all Russia). We are furthermore grateful for many discussions held at a number of international scientific conferences including EGU General Assembly, Nice, April 2004. Finally, the reviewers J.-L. Schneider and A. Strom made particularly valuable contributions and thus helped to improve the paper.

Edited by: G. B. Crosta

Reviewed by: J.-L. Schneider and A. Strom

\section{References}

Alean, J.: Ice avalanches: some empirical information about their formation and reach, J. Glaciol., 31, 109, 324-333, 1985.

Arakawa, M.: Collisional disruption of ice by high-velocity impact, Icarus, 142, 34-45, 1999.

Benz, W. and Asphaug, E.: Catastrophic disruptions revisited, Icarus, 142, 5-20, 1999.

Birk, R. J., Stanley, T., Snyder, G. I., Hennig, T. A., Fladeland, M. M., and Policelli, F.: Governement programs for research and operational uses of commercial remote sensing data, Remot. Sen. E., 88, 3-16, 2003.

Bogatikov, O. A., Melekestsev, I. V., Gurbanov, A. G., Katov, D. M., and Puriga, A. I.: The catastrophic paleolahars of the Elbrus Volcano, Northern Causcasus, Dokady Earth Sciences, 362, 7, 951-954, 1998.

Bogatikov, O. A., Melekestsev, I. V., Miller, D. K., Gurbanov, A. G., Lipman, P. W., Lovenstern, J. B., Sulerzhitskii, L. D., and Shevchenk, A. V.: Catastrophic rock-ice collapse and rapid shove of the Kukurtli Glacier (Elbrus Volcano, Northern Caucasus) in first and second centuries, Dokady Earth Sciences, 391, 5, 627630, 2003.

Chow, V. T.: Open-channel hydraulics. McGraw-Hill, New York, 680, 1959.
Coaz, J.: Statistik und Verbau der Lawinen in den Schweizer Alpen, Eidgenössisches Departement des Innern, 20-25, 1910.

Corominas, J.: The angle of reach as a mobility index for small and large landslides, Can. Geotech. J., 33, 260-271, 1996.

Davies, M., Hamza, O., and Harris, C.: The effect of rise in mean annual air temperature on the stability of rock slopes containing ice-filled discontinuities, Permafr. P. P., 12, 137-144, 2001.

Dence, M. R.: Impact melts, J. Geophys. Res., 76, 5552-5565, 1971.

Desinov, L.: Surge of Kolka glacier in 2002, Bulletin of Vladikavkaz Scientific Centre (Vestnik Vladikavkazskogo Nauchnogo Centra), 4, 3, 72-87, 2004.

Digitalglobe, Product Information, http://www.digitalglobe.com, 2004.

Dypvik, H., Burchell, M. J., and Claeys, P.: Impacts into Marine and Icy Environments. In: Cratering in Marine Environments and on Ice, edited by Dypvik, H., Burchell, M. J., and Claeys, P., Springer, Berlin, 1-20, 2004.

Ebehart-Phillips, D., Haeussler, P. J., Freymueller, J. T., Frankel, A. D., Rubin, C. M., Craw, P., Ratchkovski, N. A., Anderson, G., Crone, A. J., Dawson, T. E., Fletcher, H., Hansen, R., Harp, E. L., Harris, R. A., Hill, D. P., Hreinsdottir, S., Jibson, R. W., Jones, L. M., Keefer, D. K., Larsen, C. F., Moran, S. C., Personlus, S. F., Plafker, G., Sherrod, B., Sieh, K., and Wallace, W. K.: The 2002 Denali Fault earthquake, Alaska: A large magnitude, slippartitioned event, Science, 300, 1113-1118, 2003.

Evans, S. G. and Clague, J. J.: Catastrophic rock avalanches in glacial environment, Landslides, Proc. 5th International Symposium on Landslides, Lausanne, Switzerland, 10-15 July, 11531158, 1988.

Evans, S. G. and Clague, J. J.: Dynamics of the 1984 rock avalanche and associated distal debris flow on Mount Cayley, British Columbia, Canada; implication for landslide hazard assessment on dissected volcanoes, Eng. Geol., 61, 29-51, 2001.

Gruber, S., Hoelzle, M., and Haeberli, W.: Permafrost thaw and destabilization of Alpine rock walls in the hot summer of 2003, Geophys. R. L., 31, LI3504, 2004.

Gudmundsson, M. T., Sigmundsson, F., Björnsson, H., and Högnadóttir, T.: The 1996 eruption at Gjálp, Vatnajökull ice cap, Iceland: efficiency of heat transfer, ice deformation and subglacial water pressure, Bull. Volcanol., 66, 46-65, 2004.

Haeberli, W., Wegmann, M., and Vonder Mühll, D.: Slope stability problems related to glacier shrinkage and permafrost degradation in the Alps, Eclog. Geol., 90, 407-414, 1997.

Haeberli, W., Huggel, C., Kääb, A., Polkvoj, A., Zotikov, I., and Osokin, N.: Permafrost conditions in the starting zone of the KolkaKarmadon rock/ice slide of 20 September 2002 in North Osetia (Russian Caucasus), in: Extended Abstracts on Current Research and Newly Available Information, edited by Haeberli, W. and Brandovà, D., 8th International Conference on Permafrost, Zurich, 21-25 July, 49-50, 2003.

Haeberli, W., Huggel, C., Kääb, A., Oswald, S., Polkvoj, A., Zotikov I., and Osokin, N.: The Kolka-Karmadon rock/ice slide of 20 September 2002 - an extraordinary event of historical dimensions in North Ossetia (Russian Caucasus), J. Glaciol., in press, 2005.

Heim, A.: Bergsturz und Menschenleben, Zürich, Fretz and Wasmuth, 1932.

Hoinkes, H.: Die Ausbrüche (surges) des Kolka-Gletschers in Nord-Ossetien, Zentraler Kaukasus, Z. Gletscherkd. Glazialgeol., 8, 1-2, 253-270, 1972. 
Hsü, K. J.: Catastrophic debris streams (Sturzstroms) generated by rockfalls, Geol. Soc. Am. Bull., 86, 129-140, 1975.

Huggel, C., Kääb, A., Haeberli, W., Teysseire, P., and Paul, F.: Remote sensing based assessment of hazards from glacier lake outbursts: a case study in the Swiss Alps, Can. Geotech. J., 39, 2, 316-330, 2002.

Huggel, C., Kaab, A., Haeberli, W. and Krummenacher, B.: Regional-scale GIS-models for assessment of hazards from glacier lake outbursts: evaluation and application in the Swiss Alps, Nat. Haz. Earth Sys. Sci., 3, 6, 647-662, 2003,

SRef-ID: 1684-9981/nhess/2003-3-647.

Huggel, C., Haeberli, W., Kääb, A., Bieri, D., and Richardson, S.: An assessment procedure for glacial hazards in the Swiss Alps, Can. Geotech. J., 41, 6, 1068-1083, 2004.

Hungr, O., Evans, S. G., Bovis, M., and Hutchinson, J. N.: Review of the classification of landslides of the flow type, Env. Eng. Geol., 7, 3, 221-238, 2001.

Iverson, R. M.: The physics of debris flows, Rev. Geophys., 35, 245-296, 1997.

Iverson, R. M. and Denlinger, R. P.: Flow of variably fluidized granular masses across three-dimensional terrain: 1 . Coulomb mixture theory, J. Geophys. Res., 106, 537-552, 2001.

Kääb, A.: Monitoring high-mountain terrain deformation from repeated air- and spaceborne optical data: examples using digital aerial imagery and ASTER data, ISPRS J. Photogramm, Remote Sens., 57, 1-2, 39-52, 2002.

Kääb, A., Wessels, R., Haeberli, W., Huggel, C., Kargel, J. S., and Khalsa, S. J. S.: Rapid Aster imaging facilitates timely assessments of glacier hazards and disasters, EOS, TransAGU, 13, 84, 117, 121, 2003a.

Kääb, A., Paul, F., Huggel, C., Kieffer, H., Kargel, J., and Wessels, R.: Glacier monitoring from ASTER imagery: accuracy and applications, in: EARSeL eProceedings, 2, 1/2003, Observing our Cryosphere from Space, EARSeL, BIS-Verlag, Oldenburg, 43$53,2003 b$.

Kerle, N. and Oppenheimer, C.: Satellite remote sensing as a tool in lahar disaster management, Disasters, 26, 2, 140-160, 2002.

Kieffer, S. W. and Simonds, C. H.: The role of volatiles and the lithology in the impact cratering process, Space Physics, 18, 143-181, 1980.

Körner, H. J.: Zur Mechanik der Bergsturzströme vom Huascaran, Peru. Hochgebirgsforschung (Innsbruck), 6, 71-110, 1983.

Kotlyakov, V. M., Rototaeva, O. V., Desinov, L. V., Zotikov, I. A., and Osokin, N. I.: Causes and effects of a catastrophic surge of Kolka Glacier in the Central Caucasus, Z. Gletscherkd. Glazialgeol., 38, 2, 117-128, 2002.

Kotlyakov, V. M., Rototaeva, O. V., and Nosenko, G. A.: The September 2002 Kolka glacier catastrophe in North Ossetia, Russian Federation: evidence and analysis, Mt. Res. and Dev., 24, 1 , 78-83, 2004.

Legros, F.: The mobility of long-runout landslides, Eng. Geol., 63, 301-331, 2002.

Major, J. J.: Gravity-driven consolidation of granular slurries: implications for debris-flow deposition and deposit characteristics, J. Sediment. Res., 70, 64-83, 2000.

McSaveney, M. J.: Sherman Glacier rock avalanche, Alaska, USA, in: Rockslides and Avalanches, 1; Natural Phenomena, edited by Voight, B., Amsterdam, Elsevier, 197-258, 1978.

Melosh, H. J.: The mechanics of large rock avalanches. In: Debris Flows/Avalanches: Process, Recognition, and Mitigation, edited by Costa, J. E. and Wieczorek, G. F., Geol. Soc. Am., Rev. Eng. Geol., 7, 41-49, 1987.
O'Brien, J. S., Julien, P. Y., and Fullerton, W. T.: Two-dimensional water flood and mudflow simulation, J. Hydr. Eng., 119, 2, 244261, 1993.

Petrakov, D. A., Tutubalina, O. V., and Chernomorets, S. S.: The 2002 Genaldon glacial catastrophe: one year later, Kryosfera Semlu VIII, 1, 29-39, 2004.

Pierson, T. C.: Flow characteristics of large eruption-triggered debris flows at snow-clad volcanoes: constraints for debris flow models, J. Volcanol., 66, 283-294, 1995.

Pierson, T. C. and Costa, J. E.: A rheologic classification of subaerial sediment-water flows, in: Debris Flows/Avalanches: Process, Recognition, and Mitigation, edited by Costa, J. E. and Wieczorek, G. F., Geol. Soc. Am., Rev. Eng. Geol., 7, 1-12, 1987.

Plafker, G. and Ericksen, F. E.: Nevados Huascaran avalanches, Peru. In: Rockslides and Avalanches, 1; Natural Phenomena, edited by Voight, B., Amsterdam, Elsevier, 277-314, 1978.

Poggenpohl, N. V.: About the northern valleys of the Kazbek massif and the first ascent of the Maili Kok. Ezhegodnik russkovo gornovo ob-va, vyp. 3, 1903, Moscow (in Russian), 1903/1905.

Polyak, B. G., Tolstikhin, I. N., Kamensky, I. L., Yakolev, L. E., Marty, B., and Cheshko, A. L.: Helium isotopes, tectonics and heat flow in the Northern Caucasus, Geo. Cos. A., 64, 11, 19251944, 2000.

Popovnin, V. V., Petrakov, D. A., Tutubalina, O. V., and. Tchernomorets, S. S.: Catastrophe glaciaire 2002 en Ossetie du Nord. Unpublished french translation of an original article published in Kriosfera Zemli ("Earth Cryosphere"), 7, 1, 1-10, 2003.

Rickenmann, D.: Empirical relationships for debris flows, Nat. Hazards, 19, 47-77, 1999.

Rototaev, K. P., Khodakov, V. G., and Krenke, A. N.: Recherche sur le glacier à pulsation Kolka. M., Nauka, 1983.

Salzmann, N., Kääb, A., Huggel, C., Allgöwer, B., and Haeberli, W.: Assessment of the hazard potential of ice avalanches using remote sensing and GIS-modelling, Norwegian Journal of Geography, 58, 74-84, 2004.

Scheidegger, A.: On the prediction of the reach and velocity of catastrophic landslides, Rock Mech., 5, 231-236, 1973.

Shreve, R. L.: Leakage and fluidisation in air-layer lubricated avalanches, Geol. Soc. Am. Bull., 79, 653-658, 1968.

Smith, R. B. and Braile, L. W.: The Yellowstone Hotspot, J. Volcanol., 61, 121-188, 1994.

Swartz, M., Mc Ardell, B., Huggel, C., and Zgraggen-Oswald, S.: Modelling the Kolka-Karmadon rock/ice slide of 20 September 2002, Proc. International Conference High Mountain Hazard Prevention, Vladikavkaz, North Ossetia, Russia, 23-26 June, Abstracts, 78, 2004.

Tolstykh, M. L., Naumov, V. B., Gurbanov, A. G., Gazeev, V. M., Bogatikov, O. A., and Kononkova, N. N.: Composition of magmatic melts of Elbrus and Kazbek volcanoes, Caucasus: evidence from inclusions in minerals, Geochemistry International, 39, 4, 391-397, (translated from Geokhimiya), 4, 2001, 441448, 2001.

Voight, B. and Sousa, J.: Lessons from Ontake-san: a comparative analysis of debris avalanche dynamics, Eng. Geol., 38, 261-297, 1994.

Waythomas, C. F., Miller, T. P., and Begét, J. E.: Record of Late Holocene debris avalanche and lahars at Iliamna Volcano, Alaska, J. Volcanol., 104, 97-130, 2000.

Wessels, R. L., Kargel, J. S., and Kieffer, H. H.: ASTER measurement of supraglacial lakes in the Mount Everest region of the Himalaya, Ann. Glaciol., 34, 399-408, 2002. 